University at Buffalo School of Law

Digital Commons @ University at Buffalo School of Law

$12-12-2019$

\title{
Nof Kdumim: Remaking the Ancient Landscape in East Jerusalem's National Parks
}

Irus Braverman

University at Buffalo School of Law

Follow this and additional works at: https://digitalcommons.law.buffalo.edu/journal_articles

Part of the Land Use Law Commons, Place and Environment Commons, and the Urban Studies and Planning Commons

\section{Recommended Citation}

Irus Braverman, Nof Kdumim: Remaking the Ancient Landscape in East Jerusalem's National Parks, 4 Env't \& Plan. E 109 (2019).

Available at: https://digitalcommons.law.buffalo.edu/journal_articles/1009

Irus Braverman, Nof Kdumim: Remaking the Ancient Landscape in East Jerusalem's National Parks, Environment and Planning E: Nature and Space 4(1) pp. 104-139. Copyright (C 2021, (C SAGE Publications. Reprinted by permission of SAGE Publications.

\section{IN COPYRIGHT}

This Article is brought to you for free and open access by the Faculty Scholarship at Digital Commons @ University at Buffalo School of Law. It has been accepted for inclusion in Journal Articles by an authorized administrator of Digital Commons @ University at Buffalo School of Law. For more information, please contact lawscholar@buffalo.edu. 


\section{Nof Kdumim \\ Remaking the Ancient Landscape in East Jerusalem's National Parks}

Irus Braverman

Landscape is a historical and cultural entity, made through law, not nature - it belongs to a polity, not a species.

---John Wylie, Landscape 2007, 197.

\section{Introduction}

The national parks system worldwide has traditionally concerned itself with nature protection and with imperiled plants and animals, not with urban landscapes and human ruins (Howkins et al. 2016). In Israel, too, the historic mission of the state agency dealing with national parks and nature reserves_-Israel's National Parks Authority (INPA)—-has been the protection of nature. As stated on this agency's website: “The Israel Nature and Parks Authority protects nature, including habitats, ecosystems, and plant and animal diversity in nature reserves, national parks and open spaces" (INPA 2019).

A law passed by the Knesset in 1963 created two separate entities - the nature reserve authority, which focused on "nature," and the national parks and archeological sites, which focused on "culture." These two entities were unified in 1998 "for the purpose of fulfilling the goals of the National Parks Law, the Nature Reserves and Commemoration Sites Law and the Wildlife Protection Law" (ibid.). The mission of INPA has thus expanded from its core "green" agenda to include preserving and managing "the special look of typical landscapes throughout the country for the benefit of all inhabitants, while protecting the balance between economic, social, cultural and environmental needs" (ibid.). The dynamics and inherent tensions between "natural" and "cultural" landscapes and their preservation are an inherent part of national park administrations worldwide, and Israel is no exception in this regard (but see my critique of this binary in Braverman 2014; 2015). 
There is arguably no place that embodies the tensions between the nature and culture aspects of national parks management—and the conflicts and entanglements between different types of nature and different forms of culture in particular-more than East Jerusalem's growing chain of national parks. This article explores two national parks in East Jerusalem (in its extended, post-1967, boundaries) and the politics of their governmentalization as part of contradictory and complementary attempts at preservation, colonization, and normalization. Drawing on in-depth interviews with, and observations of, officials from Israel's Nature and Park Authority and fieldworkers from environmental and human rights nonprofits, conducted in the region between 2016 and 2019, I expose the ongoing project of Judaizing the Jerusalem landscape and the hybrid forms of colonialism that enable and that are reinforced through this project.

The natural landscape never stands for itself. "Its role in mediating social and cultural reproduction works through its ability to stand for something: norms, values, fears and so on" (Schein 2003, 202-3). In fact, "far from being an image or construction of culture-nature relations, [landscape] is their very entanglement" (Wylie 2007, 205). It is always an echo of a human presence, and in this case of a Jewish past and its modern reunion. The project of imagining the natural landscape as one that embodies an ancient past—what Israeli officials have referred to in our interviews as nof kdumim and adam ba'har - and the contemporary Jewish people as those who hold the key to its revival as such, is a crucial aspect of Israel's colonial dispossession agenda and a mandatory passage before the land can become Jewish in practice (Bardenstein 1998; Braverman 2009; Fields 2010; Long 2009; Said 2000; Zerubavel 1995). Focusing on the narratives by Israel's nature officials, this article argues that we need to pay closer attention to the messiness of the natural and cultural—or "natureculture" (Haraway 
2003) - heritage enterprise so as to contemplate how forms of colonial appropriation and environmental conservation coalesce in this context (see, more broadly, Agrawal and Redford 2009; Davis 2013; Peluso 1993; Spence 1999).

I focus, specifically, on two national park sites in the Jerusalem area: Silwan / City of David National Park, at the core of the city, and Walaje / Refa'im Valley National Park, a few kilometers southwest (Figure 1). Whereas Israeli authorities have been systematically dispossessing Palestinians by designating both locations as a national park, nature reserve, and/or archeological site, differences between the two locations also emerge that exemplify the innovativeness of the natural landscape idea. Alongside the direct takeover strategies, I also detail practices of normalization enacted in the Jerusalem parks, which include the promotion of recreation and tourism. Arguably, at both locations Jewish settlers enjoy the mostly tacit, yet increasingly explicit, support of Israel's official nature protection agencies and, in fact, in many instances they hold central positions in these agencies and constitute its ideological backbone. They are the new, yet purportedly authentic, spokespersons for nature.

My choice to focus on the national park administration in Jerusalem was not incidental. Jerusalem is, in many ways, a boundary object — both adaptable to different viewpoints and robust enough to maintain identity across them (Leigh Star and Griesemer 1989). In 1967, Israel occupied, and immediately annexed, the neighborhoods in eastern Jerusalem together with the land of 28 Palestinian communities in the adjacent West Bank into what thereafter has become known as East Jerusalem. A basic law enacted in 1980 further declared Jerusalem as the united capital of Israel. From Israel's point of view, then, Jerusalem is an integral part of its sovereign territory. From an international law perspective, however, East Jerusalem is an inseparable part of the area occupied by Israel in 1967 and is thus governed by the international laws of 
occupation, including the Fourth Geneva Convention. In practice, this legal ambiguity means that some 500 thousand Palestinian Jerusalemites live a hybrid existence: not having full citizenship but rather a "permanent residency" status, their right to continue dwelling in their Jerusalemite homes is always precarious (Shlomo 2017). Under the "center of life" doctrine, for example, if a Palestinian resident of Jerusalem lives elsewhere for a certain period she would risk losing her residency status and thus her very access to the city (Tawil-Souri 2012).

The disparity between Palestinian land and the people who inhabit it is also evident in the context of East Jerusalem's national parks, whereby the Israel Antiquities Authority, a government agency, is responsible for the excavation and preservation of archaeological sites, but the legal status of the Palestinian residents who live on top of these ruins does not enable their participation in the decision-making process that pertains to these sites. Thus, "a gap is created between the legal status of the Palestinian residents of East Jerusalem and that of the archaeological remains among which they live," which in turn engenders violations of the local communities' heritage rights (Emek Shaveh 2019c).

On the books, Israel and the occupied West Bank are each governed by distinct national park regimes. On the one hand, within the State of Israel, the Israel National Parks Authority (INPA) manages 530 national parks and nature reserves, of which 373 were officially designated under the detailed legal regime established initially in 1964 and further developed with the said merge between national parks and nature reserves in 1998 (Israel Ministry of Foreign Affairs 2015). While nearly 22 percent of Israel's land area is designated as nature reserves or national parks (Haaretz 2017), East Jerusalem's parks are distinct in that they are the only parks in the country that are situated in densely inhabited residential locations. On the other hand, in the occupied West Bank (currently Area C), the Civil Administration manages nature reserves and 
parks through the military occupation regime established there by Israel in 1967 and revised by the Oslo Accords of the 1990s. By the end of the 1990s, the Military Commander of the Area declared some 48 nature reserves and parks in the West Bank (Imadeddin 2017). The military orders impose severe development restrictions that prevent any new construction or agricultural cultivation inside the park's boundaries, as I have explored elsewhere (Braverman 2019).

East Jerusalem's national parks are arguably a hybrid between the two national park systems. While the Jerusalem parks are officially governed by Israeli state agencies according to Israeli laws, they are considered an occupied territory according to international law. The liminality of East Jerusalem can teach us about both the continuities and the slippages between national parks in these two seemingly distinct jurisdictions, and, respectively, about the fluid properties of nature protection in this region. On the ground, then, Jerusalem is a microcosm of the Palestinians' precarious condition, where one finds a porous and messy rule of law through ideas about nature that lend themselves to "gray" landscapes (Yitachel 2009). The importance of law for the formation of landscape was emphasized by geographer Kenneth Olwig, who defined landscape as "a nexus of law and cultural identity" (Olwig 2002, 19). Hybrid legalities are intricately connected with, and mutually reinforced by, hybrid landscapes as well as hybrid forms of colonialism — namely, ones that travel in between settler colonial and colonial regimes (Busbridge 2018; Veracini 2006; 2013; Wolfe 2006).

Place Figure 1 here: National parks and nature reserves in the Jerusalem area, 2018. The national parks discussed here are marked as "Walls of Jerusalem" and "Nahal Refa'im." Courtesy of Emek Shaveh.

\section{Childhood Landscape and Memory in Jerusalem}

While it may seem removed from mundane life, law is in fact deeply entangled with personal stories of "lives lived," with biography and narrative (Wylie 2007, 210). Telling such small stories can thus serve as a supplement, and at times even an antidote, to the grander 
narratives of history. Specifically, the landscape is arguably written through the subjective tensions between legal and illegal, movement and dwelling, memory and forgetting, and outside and inside. In the words of geographer John Wylie: "The notion of landscape and self [is] essentially written through experiences of mobility and exile" (2007, 211; see also Dubow 2004; Sebald 1998).

Although I grew up in Jerusalem after 1967, when East Jerusalem was already occupied by Israel and then immediately annexed, I do not have childhood memories of visiting the City of David, its Shiloah spring, or its water aqueduct. The landscape of my youth was, instead, the Palestinian village of Tsur Bacher, an eclectic jumble of stone houses hugging the hill that filled the view from my bedroom window, since we lived in the last row of houses in old Talpiot. This was also the landscape that adorned my childhood paintings.

My first encounter with the City of David came much later, during my military training as an education officer ("mashakit hinuch"). I was one of a handful of officers selected to educate soldier groups in and about Jerusalem. The City of David was the first topic we taught in every weeklong training seminar ("sidrat hinuch"). We would stand in the Haas Promenade that overlooks Jerusalem from the south and ask the soldiers to erase everything from the landscape and imagine this point of origin. We would then point to the exact location where the settlement in Jerusalem and, with it, the people of Israel, were formed. What was much less present in our educational narratives, if at all, was the complexity of the contemporary Jerusalem landscape. And thus the village scenery of my childhood was replaced by a more unidirectional narrative that focused on resurrecting the biblical past through archeological ruins without consideration of the houses built on their top or of those who currently dwell in this landscape. 
A few weeks into my idyllic instruction days in the army, in December 1987 the first Intifada, or Palestinian uprising, had begun. I have a blurry memory of myself inside the wet underground aqueduct within the City of David compound, attempting to climb out into the light of day but trapped by stones hurled down toward me and the soldiers I was responsible for. I remember wondering: what did we ever do to these people that would make them so angry at us? The two to three years of military service, which for many soldiers are a time of patriotic indoctrination, equipped me instead with painful realizations about Israel's colonial rule, and after it ended I hadn't set foot in the City of David for more than thirty years.

Until the summer of 2019, when I visited from New York in an attempt to schedule an interview with the director of Elad, the rightwing Israeli nonprofit organization that now manages the City of David National Park. A few hours after David Be'eri agreed to speak with me and show me around the park, his secretary called to cancel the interview and visit. They were unwilling to suggest any alternative times. I decided to stick with my plans to visit the park, but to do so as a tourist. The site was nothing like I had remembered. The extensive excavations that took place there since the 1990s resulted in new visitor areas. The tucked-away entry became a massive one, replete with large signs, a souvenir shop, and changing rooms. And while the receipt I was handed upon payment was for entry into a national park, and so were the flags and signs positioned across the site, the night shows, special tours, and regular e-mail prompts that began flooding my inbox since the visit were less typical of a state park and more in line with a commercial tourist attraction. This normalization, and capitalization, of the park as a recreational site is arguably a central tactic in rendering it part of the natural landscape, one that is readily available to tourists who are shopping for a spiritual experience during their visit to the 
Holy Land, as well as to Israeli students and soldiers who are thus taught biblical lessons about national and ethnic belonging.

Place Figure 2 here: The entrance to the aqueduct, with a guard and signs indicating that this is the Warren Shaft and part of the City of David National Park. A Jerusalem municipality bench on left. Photo by author, July 5, 2019.

Place Figure 3 here: The "Herodian Street." New makeshift excavations in the City of David create an underground link between the City of David and the "Temple Mount" and Old City. Photo by author, July 5, 2019.

Place Figure 4 here: Palestinians and leftwing groups protest against another demolition order in Silwan at the entrance to the City of David National Park. The signs read Dai La'Kibush ("End the Occupation"). Photo by author, July 5, 2019.

\section{Silwan: The City of David National Park}

The current national parks system in Jerusalem was established through a series of legal designations. In 1974, Israel designated the National Park "Jerusalem City Walls - City of David" as a green belt around the Old City Walls. This national park already existed in the British plans and was later recognized by the Jordanians, who controlled this area from 1948 through 1967. In our interview, urban planner Efrat Cohen Bar of the nonprofit organization Bimkom for Justice in Urban Planning distinguished between the "innocent" and "not so innocent" eras of national parks management. In her words: "if the Old City Walls park was part of the British Plan and the ideal of separating the old from the new, then Tsurim Valley National Parks that was declared in 2000 and the Mount Scopus Slopes National Park that was declared in 2005 are part of the current, not so innocent, era" (Cohen Bar, interview). The City of David National Park is the pulsing heart of the "not so innocent" era, according to Cohen Bar. Although one might contest her characterization of the British Mandatory designations as innocent (see, e.g., Schorr 2014), the differences between the historic and the more recent designations in Jerusalem, which have only intensified in the last decade, are worth consideration, if only for 
acknowledging the changes in the legal, administrative, and political modes of governing these parks, which, again, result in the landscape's making.

After 1967, massive archeological excavations commenced in the City of David.

Managed by Israel's Antiquities Authorities, these excavations have centered around the Gichon spring and the Shiloach tunnel. The digs have only intensified since Elad started managing the site in 2002. In 2018, the Israeli government allocated a record sum of approximately 15 million US dollars for archaeological excavations in Silwan / City of David (Emek Shaveh 2019b). For the 40 thousand or so Palestinian residents of Silwan, the inclusion of their village within the national park has meant that they have been subject to draconian restrictions on construction and renovations (ibid.). These residents claim that the Israeli authorities have made it virtually impossible to obtain building permits, and so they are compelled to construct illegally. Such illegal constructions have in turn resulted in over one hundred demolition orders in Silwan. The year 2019 also saw a significant increase in the number of Palestinian residents of East Jerusalem who have had to demolish their own home to avoid paying the city had the municipal authority carried out the demolition (B'Tselem 2019; for a broader exploration of the forced adaptation to Israeli and municipal administration see Shlomo 2017). At the same time, the archaeological digs have weakened the foundation of many of the physical structures in Silwan, in turn resulting in the need for further construction, which is, again, deemed illegal — and so the cycle of illegality continues to spiral (Braverman 2007).

Meanwhile, the rightwing Jewish groups Ateret Kohanim and Elad have been purchasing Palestinian properties in the area, with the explicit goal of Judaizing East Jerusalem. In 2015, 54 outposts accommodated approximately 400 Jewish settlers in the Al-Boustan and Wadi Hilweh neighborhoods of Silwan (UN Human Settlements Programme 2015). In 2018, Amendment 17 to 
the National Parks, Nature Reserves and Memorial Sites Law was underway. The Amendment, entitled "Planning for Housing in an Existing Neighborhood in a National Park," would apply only to the City of David National Park, thereby overturning the long-standing legal prohibition against building inside national parks. This Amendment has been perceived by many as intended for the sole purpose of legalizing the otherwise illegal constructions by Jewish settlers within the park (Haaretz 2018).

Nowadays, the relationship between the Antiquities Authority, INPA, and the East Jerusalem settlers is nothing other than symbiotic. But this has not always been the case. To understand how the current situation has come about, it is necessary to step a few years back. Toward the end of the first Intifada in the early 1990s, Israel's Antiquities Authority came into conflict with the East Jerusalemite settlers and their political patrons led by then Minister of Housing Ariel Sharon. The settlers wanted to build 200 residential units on the ruins of the City of David, but the Antiquities Authority refused to grant them permits. The Authority's legal advisor explained this refusal: "The Antiquities Authority categorically maintains that it is vital to preserve the City of David, and that no construction whatsoever should be conducted at the site. Only archaeological excavations, works of conservation and reconstruction should be undertaken in the City of David area" (quoted in Emek Shaveh 2014a; see also Emek Shaveh 2013; 2014b). A decade or two later, development plans in the City of David are now promoted collaboratively by the Antiquities Authority, INPA, the Jerusalem municipality, and the Elad Association (ibid.).

How to explain this dramatic change in policy? Following a petition to Israel's High Court of Justice in 1998, the Israel Lands Authority withdrew its plan to hand over the area to the Elad Association and, at the end of 2000, the site was placed under the authority of INPA. In 
practice, however, in 2002 INPA signed a contract with Elad that authorized Elad to manage and operate the site. According to the Israeli nonprofit Emek Shaveh, this constituted "the complete surrender of control over scientific and tourist activity in Jerusalem's historic basin to religious entities with a clear agenda." Emek Shaveh further claimed that

For the government and the settlers, archaeology has become a political tool of the highest order.... The transcripts, e-mail exchanges and financial balance sheets upon which this report is based tell an extraordinary tale of how a government agency becomes party to the agenda of a rightwing association, of how this association's values are adopted by a public service, and of the manner in which the history of Jerusalem is recast as a marketable national (Israeli) commodity (Emek Shaveh 2014a; see also Mizrachi, interview and Abu El-Haj 2008).

In July 2017, Prime Minister Benjamin Netanyahu announced his plans for the completion of the Kedem Center-a seven-story building spanning an area of 16,000 square meters, at the heart of the City of David / Silwan. This development is part of a larger project that will include a cable car over the protected Ben Hinnom Valley and new access routes to the Western Wall, circumventing physical passage through the Palestinian parts of East Jerusalem and thus making access more predictable, controllable, and marketable. While such massive developments have been taking place in its surroundings, the Shiloach pool itself is still not fully excavated nor fully developed due to ownership disputes with the Greek Orthodox Church (Figure 5). Despite attempts to conceal this at the general site, the pool and its spring are very much a microcosm of the park's legal-natural landscape of contest and ruin (see also Braverman 2019).

Place Figure 5 here: A tourist group outside of the Shiloach pool in the City of David National Park, amidst the "refugee camp landscape" of the Palestinian village of Silwan. Photo by author, February 2018.

In spite of the contest, ruin, and dispossession embodied in this landscape (or precisely because of it), some 500 thousand visitors, Jewish American tourists as well as Israeli students and soldiers, still flock to the City of David every year. In one of the park's central attractions, 
visitors are promised an adventurous wet experience by walking through the underground First Temple aqueduct. And although the narrative promoted by the park's visitor center has a distinctly Jewish focus, an official from the Israel Antiquities Authority stressed that "the work we do here is not about looking for a particular heritage of one or other. We find what there is and display what there is" (BBC 2010). I will revisit this universalist heritage scheme shortly.

At the same time, the close administrative ties between the rightwing settler group of Elad and INPA are not even hidden as the current director of the latter is an ideological settler himself, and served previously as Chairman of the Yesha Council (the umbrella organization of municipal councils of Jewish settlements in the West Bank). A report issued by Emek Shaveh thus asked in this context:

What's the connection between a National Park and a political conflict? Why is it Jerusalem, of all Israeli cities, that has the most national parks, and why are most of them in East Jerusalem? How are archaeological sites and excavations used as tools in the struggle for public opinion, and as a means of taking control of lands belonging to Palestinian residents? (2014a; see also Greenberg 2009; Kersel 2015).

The project of rendering East Jerusalem's national parks, nature reserves, and archeological sites accessible and even popular tourist sites is arguably a central tenet in the normalization of Jewish settlements and the Judaization of the landscape more broadly. Under the rubric of recreation and entertainment, the national park status of parts of Silwan allow the public to feel comfortable by obscuring the particular geopolitics of this occupied and conflicted site and making it into a park just like any other. It would, accordingly, be a mistake to think that the passion for archeology and biblical connectivity are only experienced by rightwing radicals. Indeed, the City of David National Park is one of the mandatory sites promoted for school fieldtrips that is included in curriculums across the country. Such normalization practices that occur in the territories occupied in 1967 are thus inseparable from the Zionist (settler) colonial ideology as practiced within Israel's 1948 borders and in turn also seep back into the occupied 
territories (Allegra et al. 2017, 3). Nonetheless, the process of erasing the City of David National Park's particular geopolitical location through its normalization as a tourist recreation site is arguably incomplete, as many Jewish Israelis—my family and friends included—still view this part of East Jerusalem as dangerous and refrain from visiting there.

\section{Green-Gray Legalities in Jerusalem}

INPA directly manages all national parks and nature reserves within Israel. This form of management is complicated in the urban and political context of Jerusalem, where the park constitutes "an authority within an authority," thereby illuminating both the tensions between, and the creative powers of, the combined governance by a national nature authority and a municipal body. From INPA's perspective, the City of David National Park is part of a much broader and more ambitious Master Plan for green corridors in and around Jerusalem, newly referred to as the Jerusalem Park.

The Jerusalem Park is the largest national park in Israel and encompasses 15,000 dunam, or 15 square kilometers. The reason that these areas were not simply declared green zones within Jerusalem's municipal plans but were instead designated as national parks under the National Parks Law, as one INPA official explained to me, was the realization that this area needed a long-term vision that would not be swayed by mundane politics (INPA official "C," interview). Indeed, once a national park or nature reserve is declared, it is considerably difficult to alter this designation. "It's a law that the state made to tell itself that these are national assets that need to be preserved for generations. And once a space has been declared, it means we have formed this decision for years" (ibid.). In other words, the national park landscape is perceived as stronger than everyday politics and as reflecting the interests of future generations. At the same time, it sets in stone (often literally) a particular way of seeing that de facto strips current owners of the 
land from many of their rights, including the right to build and in some instances also the right to cultivate and graze within their private property. In the name of a benevolent public need for green space, certain populations - but not others - are deprived of their ownership rights without compensation, as a national parks designation is neither considered a legal taking nor an appropriation (Braverman 2019). This again brings home the understanding that "law plays a central role in the constitution of landscape" (Olwig 2005, 296). The rule of law becomes even more important in the face of the apparent injustice of Israel's dispossession of Palestinians, contributing to hyperlegal landscapes subject to intense classifications and heightened surveillance and control (Braverman 2019).

In the 1990s, INPA authorized the Jerusalem municipality to manage the national parks within the city's boundaries. This arrangement eventually led to considerable tensions between the two government bodies. INPA official "C" recalled:

In 2000, we ... found that Ben Hinnom Valley was the biggest dump yard in Jerusalem. I mean, every East Jerusalemite who had to throw a dead donkey did so in the Wadi [valley] down here below [points to site]. And when we started removing waste, we additionally found waste of the Jerusalem municipality itself that was doing work to preserve the Jewish quarter and dumped waste here in the Ben Hinnom Valley.... We restored all of this. People live here. These are private parcels, and [Palestinians] were suspicious of these [changes] initiated by us. [They were convinced that] first we would come to their land and start working here, [and then] the settlers will come and take it. We told them that we're coming here and arranging and cleaning, [but] these are your trees, and you get the olives (interview).

Again, the INPA officer sees his work as concerned only with waste removal and other such benevolent green initiatives that pertain to the landscape and its management, which the Palestinians in turn interpret as political, thus supposedly confusing the fair and neutral conduct of the nature agency with the settlers' political dispossession tactics. On the ground, however, a much less categorical distinction between settlers and INPA is at play, as I have shown. 
A more recent legal strategy deployed by INPA for "cleaning and greening" the Jerusalem landscape has been its utilization of Gardening Ordinances. These provide yet another apt example of INPA's ingenious legal creativity when it comes to managing private Palestinian lands in Jerusalem, this time by deploying a municipal power that it would not possess otherwise. In the words of INPA official C:

The municipality can enter private property that is neglected and garden it. It doesn't appropriate it, doesn't take it, not mine or yours, I'm just cleaning here. You're entering someone's private property and gardening it. Even within a national park, I can't enter someone's private property [to do such a thing].

The utilization of municipal powers by a national authority highlights the strategic benefits of the hybrid national-urban park in the Jerusalem setting. Such gray legalities provide an opportunity for further control of the landscape and its residents. In 2017, Bimkom petitioned the courts against the greening ordinances practice for its violation of Palestinian ownership and won, albeit for technical reasons (Cohen Bar, interview).

\section{Refugee Camp Landscape vs. Nof Kdumim}

While the cultural and natural emphases may, and often do, result in uneasy tensions between and within Israel's national parks and archeological authorities, in East Jerusalem they are deployed interchangeably as complimentary technologies of dispossession and are connected in myriad ways. Notably, the greening of the Jerusalem landscape is not strictly an environmental project; it is also a central tenet of the visual and discursive making of this landscape into nof kdumim —an ancient (read: biblical) landscape. As INPA official "C," himself an orthodox Jew and a settler, explained: "We want to make [this area] look like the built landscape that should surround ancient Jerusalem, and not the refugee camps landscape that it currently is. To do this, you need a plan." Memory and identity become embodied in the landscape through detailed zoning plans and legal schemes. 
Edward Said insisted that the promotion of a convincing narrative that would accompany the imaginary landscape is a necessary precursor to the actual remaking of the physical landscape and one of the powerful successes of the Zionist enterprise. In his words: "What we never understood was the power of a narrative history to mobilize people around a common goal. In the case of Israel, the narrative's main point was that Zionism's goal was to restore, reestablish, repatriate, and reconnect a people with its original homeland" $(2000,184)$. Along the project of drawing connections through landscaping practices, Said also discussed the project of active elimination through the landscape, highlighting that "the Jewish discourse eliminates from the landscape the former Palestinian presence" (ibid., 191; see also Bardenstein 1998; Zerubavel 1995, 63). "I have a role," the INPA official told me as we stood on Mount Scopus, overlooking the Judean desert toward the east (Figure 6) (his tone reminiscent of MLK's "I have a dream"). He then outlined the proposed plan for Mount Scopus Slopes National Park:

I need to promote what, in my eyes, is worthwhile for preservation for future generations. [Most importantly,] we need to preserve nof kdumim. We in INPA respect all the cultures that have passed through here for thousands of years: Christianity, Islam, Judaism, the New and Old Testament. Jerusalem is not a private story of ours. Jerusalem has its own story, and it is this story, along with a wide array of others, that we want to preserve (interview, INPA official “C”).

This vision of an egalitarian battle between the refugee and the biblical landscapes is especially ironic, as the refugee landscape is in fact very much a result of the ideology underlying the biblical one — indeed, its violent and spectacular imposition — rather than a landscape of choice by Palestinian Jerusalemites. In this sense, the making is always a remaking — and requires an elimination of another landscape, which is a central feature of settler colonialism (Wolfe 2006). 
The director of the Kfar Etzion Field School, Amichai Noam, presented a similarly cosmopolitan vision of the Jerusalem landscape when he referred to the human relationship with this ancient landscape and its surrounding hills as adam ba'har ("man in the mountain"). He explained:

It doesn't really matter who lived here over the last thousands of years: the culture of the traditional life in the mountain region of the Land of Israel is the same mountain culture that the person who founded it created. The specific man changed, but the culture stayed, and through this culture you can understand much better the environment as it is today, the Arab neighbors who live next to us, and also our own past. If we want to understand how our ancestors lived in this mountainous terrain, the best way to do it is to understand the importance of adam ba'har (Noam, interview).

Pointing from his living room window toward the hilly landscape of the nature reserve that borders his back yard in the Jewish settlement of Tkoa (south of Jerusalem), Noam outlined his detailed socio-ecological approach. For him, the sense of identity and connection is derived from an understanding of the landscape as a topographic and ecological zone that offers particular climatic conditions that in turn dictate a certain social life. While supposedly not concerned with the specific identity of the humans who have lived there over the years, this unique way of life draws a connection between the current Jewish settlers of this place and their biblical forefathers, who, per this narrative, were an early, if not the earliest and thus purportedly the original, link in this chain of mountainous tradition.

Both the nof kdumim and the adam ba'har concepts express the value of the geophysical terrain and its longstanding natural heritage. What is masked by these universalist concepts, however, is that the landscape imagined through them then enables and also justifies the erasure of existing landscapes that do not comply with this imaginary, and the "refugee landscape" first and foremost among them. Joanna C. Long further explained, albeit in the context of JNF's arboreal landscaping project, that: "the innocence and organicism [] naturalises this dispossession by creating a harmonious scene that is imagined to exist somewhere beyond 
politics. There is, of course, nothing natural about the process of Zionist colonisation. [] [T]hese landscape imaginaries [] have been mobilized to perform important geopolitical and ideological work towards the establishment and perpetuation of Israeli nationhood" $(2009,74$; see also Bardenstein 1998; Braverman 2009).

Place Figure 6 here: "Nof kdumim" (the ancient landscape) as seen from Mount Scopus during an observation with INPA official "C." Photo by author, February 2018.

\section{"I Come for the Birds": How INPA Officials See the Landscape}

INPA official "C" has been quite frustrated with the maneuvers that his proposals for the Mount Scopus National Park have sparked on both the left and the right of the political spectrum. "From the right," he told me, "the Mayor of Jerusalem and that of Maale Adumim say that the national park is [a great plan] because it will connect Jerusalem to Maale Adumim. But this isn't good for me, because it's making my story into a political one, while I honestly believe that this

national park will preserve nof kdumim — the ancient landscape of Jerusalem—for generations to come." While one might suggest that the national parks designation is a ploy intended for colonial ends, it is clearly not experienced as such by the individuals who work in these positions, thereby affording us a glimpse into how individual psychology enables this legal regime to persist, and to justify itself, on the ground. Notably, however, in Har Homa (a few kilometers southwest of Ma'ale Adumim) the national park has not provided such strict protections when it came to enforcement against Jewish settlers, despite their noncompliance with the nof kdumim ideal, and so, too, was the case in the Wadi Kana and Umm Zuka nature reserves in the West Bank (Tatarski, interview).

Although he believes his vision as being exclusively concerned with nature protection and thus as apolitical, this INPA official simultaneously holds that the importance of the legal protection of the landscape provided by the national park status stems from the historical value 
of the landscape and its ties to the cultural heritage of one particular group: the Jewish people. It then follows, for him, that as long as the local Palestinians help preserve this particular natureculture landscape (namely, if they are native enough to support orientalist environmental imaginaries), they may stay. The Palestinian presence is thus always conditional- they are treated as means toward the end of reconstructing another people's imaginary and physical landscape. This is an excellent reminder of one of the central features of colonial (but not of settler colonial) projects, which seek to emphasize the distinctions between settlers and natives (Veracini 2013; Wolfe 2006), yet here with a local twist: in the revised order of things, the "newer" native (namely, the Palestinian) is allowed to exist (dwell, cultivate) only in so far as her identity forms and informs the allegedly more "original" native (namely, the Jew). Nativity becomes a matter of degree, presenting yet another instance in which green becomes gray. INPA's perspective on natives, nature, and Palestinians was on colorful display in an interview I conducted with one of its former inspectors (herein: INPA official "B"). This interviewee described Israel as an "island" of nature protection amidst a sea of Arab degradation, with East Jerusalem as a corridor between these two conflicting geographies and worldviews. In his words,

Because they hunt without any barriers anywhere in the Arab countries, Israel stays relatively abundant in terms of nature, kind of like an island, for some of the species [at least]. And then [the Palestinians] hunt here, pass it to East Jerusalem and from there to the territories. Now, every time we get a warrant to bust places in East Jerusalem, people are like, "You're oppressing us because it's East Jerusalem." That's Bullshit! I come for the birds. Shmulik, Amsalem, Ahmed, or Joe-I really don't care, here or there (interview; see also Braverman n.d.).

According to this INPA official, his work is about protecting goldfinches and gazelles ("I come for the birds") and has nothing to do with humans. "I don't care about politics. Nature, and nature alone, is my flag," another INPA official told me (Hatzofe, interview). Such a "nature is our only flag" narrative could be challenged in this context, as the densely populated villages of 
East Jerusalem are hardly the typical setting for a national park (and indeed, as I already mentioned, this is the only place where Israel designated parks in the midst of a densely built environment). At the same time, one must realize that the INPA officials are also authorized to protect wild animals wherever they might be, i.e. also beyond the boundaries of these parks. Accordingly, one of the Jerusalem inspectors told me in great detail how goldfinches are trafficked and sold in East Jerusalem's black market and how the illicit wildlife trade takes advantage of the gray areas—-both physically and legally—of this conflict zone to make quick profit (INPA official "D"). On his part, INPA official "B" doesn't agree that the problem is economic, insisting that it is part of a stronger cultural preferences. In his words:

It's very common with the Arabs, [who believe] that God gave us these animals so we can hunt and eat, and for no other reason.... They really like to shoot. We're on the bird migration line to Africa. They love shooting at the birds when they're in flight. It happens] everywhere all the time! It's illegal. They shoot, and then we treat them in Israel (INPA official "B").

Highly versed in the contemporary literature on Indigenous hunting rights practiced elsewhere, this officer further emphasized that, unlike in those contexts, hunting by “Arabs" isn't a form of sustenance, but is performed solely for entertainment purposes. He finally concluded:

At the end of the day, after all the philosophy and humanism - and I'm all for humanism - you need to take a stand. You need to decide, otherwise you can ride the fence and endlessly talk about whether it's okay to let them hunt porcupines and turtles because it's part of their social culinary heritage or not. But by the time you finish thinking about this, there will be no more gazelles! (ibid.)

From INPA's perspective, then, Israel operates as an island of humanism and legality, protecting its natureculture heritage, which includes vulnerable wild species, from the destruction wrought by the Palestinian savage. "Palestinians and Arabs really like to eat porcupine," this official told me, commenting about their cruelty when, while hunting, they unnecessarily strike porcupines over the head until their painful death. Situated in between these two bifurcated modalities of enforcement, East Jerusalem is, again, a hybrid space: not 
completely militarized yet not fully integrated, enforcement here is executed by INPA, alongside the military police (magav). Animal bodies and mobilities, such as those of the goldfinches trafficked through East Jerusalem, defy the normalization of the landscape, exemplifying its fluidity and instability on the ground (see also Braverman, forthcoming; Gutkowksi, forthcoming).

\section{Walaje: Refa'im Valley National Park}

A few kilometers from Silwan / the City of David as the crow (or the goldfinch) flies, the village of Walaje is situated both within and outside of the Green Line and is thus caught between the Separation Wall and the Jerusalem municipality (Joronen 2019). Recently, the village's agricultural lands were also designated as a national park, which celebrates the ancient terrace features that have preserved traditional agricultural practices. Additionally, the village's spring (Ein Hanya) and its surroundings were designated as an archeological park due to findings excavated there from the First Temple and early Christian eras (Shuster \& Hasson 2018; see

Figure 7). Similar features in the nearby village of Battir have led to its designation as a UNESCO Cultural Heritage Site (UNESCO n.d.). INPA's official explained the importance of the natureculture features of both terrace and spring and thus the justification for their protected legal status at this site:

The farmers in this area used two agricultural methods: one is the manmade springs and the other is the terraces. All these springs, they built pools around them and from these water pools systems of cisterns provided water from the high point downhill to areas where they grew vegetables. The terraces were built on steep slopes that couldn't be cultivated, in turn making them available for agriculture. They create a horizontal space, while also storing the rainfall and enabling more seepage of the water-i.e., more water in the system. They say that terraces started in the First Temple period. The Book of Isaiah suggests that the most fertile land was with the Philistines, and that in order to create agriculture, the Israelites needed to settle the hills and transition them into agricultural lands. Terraces have then become the local enterprise for generations. Every household that has made the land arable passed it on to their kids who needed more, so they built and expanded. This didn't happen in one day. If the terraces were abandoned, a 
few dozens of years and they would disappear. They needed constant upkeeping. Rain comes and it seeps into the ground and rocks fall and roll downhill and then also the terrain that supports the terraces gets washed away and it goes back to being rocky land. After the Jews were exiled, these terraces have continued to be the agricultural enterprise of anybody who came to this region and lived here (interview, INPA official "C"; emphasis by author).

\section{Place Figure 7 here: Palestinian Israeli lawyer Quamar Mishirqi-Assad at Ein Hanya during INPA's restoration of the spring, Jerusalem National Park. Photo by author, February 2018.}

In 2002, the newly constructed Separation Wall left the Hanya spring and most of Walaje's terraces on the Israeli side, while the villagers who privately own the land that the spring is situated upon, and who have maintained the spring and cultivated this land for centuries in certain instances, have come to reside on the other side of the Wall (Figure 8). According to Aviv Tatarski, an Israeli activist from the nonprofit Ir Amim who has supported the village's struggle for over a decade, the spring used to be a local meeting place for all. "You could come and see Palestinians and Israelis, even settlers, sitting around the large pool of water," Tatarski told me (on the importance of springs as natureculture anchors in the occupied West Bank see Braverman 2019). In 2016, INPA embarked on a major renovation of the spring as a central component of the Jerusalem Park project. This involved moving the existing Walaje checkpoint into Area A and therefore depriving access to the terraces and spring to Palestinians on the other side of the Wall, even though they legally own this land. One of the Palestinian farmers showed me the tunnel he must travel through to visit his forefathers' graveyards and told me about the tenuous access arrangements he has had to negotiate to visit this sacred site (Abu Bassem, Mishirqi-Assad \& Tatarski, interviews).

Place Figure 8 here: Overlooking Walaje: mountains, terraces, and the Separation Wall. Photo by author, February 2018. 
More generally, Tatarski described the dichotomy between Israel and the West Bank

when it comes to park management, and Jerusalem's hybrid and liminal status in this context. In

his words:

In nature reserves there are more regulations and limitations than in national parks. But once you designate them, both are regulated under the Israel Nature and Parks Authority. The implication is that human activity needs to be limited. Even if you own the land privately, it is not expropriated, but what you can do with the land is severely limited. In the occupied territories, since a lot of the land is privately owned by Palestinians, one of the methods is to take the land without officially expropriating it, and then suddenly they become under the authority of an Israeli body. This is what happened in Walaje. The Jerusalem municipality, together with the Israel Nature and Parks Authority, are now advancing a park called Refa'im Valley on these 1,200 dunams. Because it's considered Israel, and the Israeli law applies - unlike Wadi Kana where it is a military rulebasically the law offers lots more regulation and protection to the residents. Theoretically, this dictates an entire process that is supposed to protect their rights. But that's not actually the case (interview, December 2016).

Again, the gray legalities imposed on a landscape that has come under Israeli sovereignty, which does not include granting citizen rights to the people residing on this land, enable practices that reorder the landscape so that it closely aligns with the Jewish national enterprise.

Tatarski also described the roundabout way in which he had found out about the plans to designate Walaje's private lands as a national park:

One day, I went to Walaje to visit one of the activists I know there. I went on a road that is not supposed to be for Walaje residents, as it leads to Jerusalem, where they are not officially allowed to go. I saw a new sign on the side of the road, and so I stopped. The sign was only in Hebrew, which most residents can't read. It declared the plan to construct a national park. I took a photo and alerted my friends in the village. It could've happened without the village knowing about it, which goes to tell you about Israel's regard of Palestinian ownership rights. The reason [INPA] gave for constructing the park is that it was created by an ancient farming heritage. They suggested that it may be the only living example of a biblical landscape. The terrace landscape in Walaje is supposedly how the land of Judea looked like 2,000 years ago (ibid.).

This quote highlights the porousness between the nature regime practiced in East Jerusalem and that practiced in the West Bank, when the local population is not even assured proper notice about a park's designation, not to mention participation in the proposed plans. For Tatarski, this 
story highlights how Israel uses nature to obfuscate political interests, and how the landscape is employed to reimagine the temporalities of this place and the rightful presence in it of certain populations only. As he recounted:

Why is this story so important? One part is the usual way that Israel puts the past over the present: it is now Palestinian land, but it used to be part of the Jewish heritage. So we can imagine what it used to be in the past, and in the name of our historical rights we can then disregard present rights. But if you're so interested in traditional agriculture-no modern machinery, no tractors, everything by hand, organic, irrigated by spring water, just like it was 500 and 2,000 years ago - if that is so important to you, you should be concerned about the farmers, not only about the landscape. [They are those who] keep it alive. But the documents of the national park service don't mention Walaje at all. Not even one sentence mentioning the farmers who today, not in the past, are creating this landscape; who are needed, today, to keep this landscape alive. And there's no talk about the threat to this landscape by the Separation Barrier. [They] only talk about creating a natural area for the wellbeing of [West] Jerusalem's residents.

According to Tatarski, then, the designation of national parks is a means for imposing the Jewish past upon the Palestinian presence through the construction, and then the preservation, of the physical landscape. INPA official "C" expressed this exact notion in our interview when he exclaimed that:

The important asset or value of a heritage landscape is that it is maintained by the people like it was originally, or like it was in the past. The objections from Walaje were that we found a way to nationalize our lands and take them. We declared, and we stand behind this, that all of their lands are still theirs. That's the law. A natural reserve is not an appropriation of private land, it is a designation of this land. And the designation here is to keep the terraces and the old traditions alive. The more the locals do it themselves, the better for the national park.

Utilizing a hair-splitting legal distinction between appropriation and designation, this

official insists on seeing the nature-law landscape as fair and just. According to this narrative, the Palestinian body needn’t be physically eliminated. Instead, her labor and identity can be efficiently appropriated to contribute to the larger project of making the Jewish homeland into the imaginary and physical landscape of nof kdumim, namely - the way it supposedly looked like when the Jewish forefathers lived there (see also Noam, interview). This practice, which may be 
referred to as "self-indigenizing by proxy," presents a mimicry of the imagined past, which is in fact forced upon the colonized population. The Jewish people are in turn construed as the original, and thus more indigenous, people of the region (Zureik 2015). Alongside the display of an authentic and connected Jewish landscape, a compartmentalized reality is at play that enhances the precariousness of the Walaje landscape. Mikko Joronen wrote in this context: "Area C, Area B, seam zone, and the Jerusalem part of the village—are run by different (but overlapping) regulations, permit systems, and logics" (2019, 852; see also Berda 2017; Chiodelli 2017). Again, legal permutations dictate physical and discursive landscapes, which in turn feed back into the legal terrain.

The ideological significance of the particular national park regime in Jerusalem in rendering the past legible through the landscape was further illustrated by INPA official "C", again providing a window into how these officials, and possibly also the settler communities that some of them are part of, justify these practices. In his words:

Everyone says "Wow" about the amazing archeology of the Roman culture that was here and utilized thousands of slaves. But our Forefathers, they didn't leave such an archeology or places with the same "Wow." The connection that they left for us in the landscape are terraces and olive presses. Even their houses didn't really survive because they had simple houses like the fellahin [i.e., the Palestinian farmers]. You can't see it, because you don't have an archeology of their life. This, here [points to the Palestinian terrace landscape], is our archeology, our people's archeology. When you see the view of the Land of Israel - the view around Jerusalem, the corridor from Jerusalem westwardthat is the real culture of the simple people who lived here. This culture is manmade. And when you keep maintaining and using it, its value grows to be outstanding. You can see here the village of Battir. The terraces out there, they're green, they're green with lettuce, parsley, all types of vegetables (interview).

The involvement of local Palestinian farmers in the protection of the allegedly ancient terrace landscape is also an inherent part of an ecotourism scheme that draws on the historical uniqueness of the area-solidified under UNESCO's designation of one such terrace systems as a world heritage site - to celebrate and promote it as a normal and legitimate recreational site 
rather than one of dispossession and elimination. Relatedly, in the name of protecting the terrace culture of this place (and the adam ba'har ideal), Jewish settlers from Gush Etzion and Palestinians from the neighboring villages have come together to oppose the construction of the Separation Wall in this area (Reynolds 2017; Noam, interview). They were later joined by no other than INPA in a dramatic statement to the Supreme Court against the Israeli government's position - pitting one government agency against the other (Katz-Mink 2012). Nature yet again emerges as an ostensibly apolitical project that transcends and erases differences, thereby promoting a supposed normality. At the same time, across the hill from Walaje, Palestinian farmers were hired under contract from INPA to tend to the terraces in another national park (reminiscent of Salim Tamari's discussion on "building other people's homes"-here, other people's natural landscapes; see Tamari 1981). When the Palestinians were no longer able to access the park because of the Separation Wall, trained INPA officials promptly took their place (Tatarski, interview).

Alongside INPA's territorial practices that de facto control and dispossess Palestinians, which highlight the continued juxtaposition of settler and native and are thus a central tenet of colonialism, other practices are also at play here that are meant to eliminate the native through integration and normalization — specifically, by making the national parks into sites of modern and global tourism - practices that are more characteristic of settler colonial practices (Busbridge 2018; Veracini 2006; Wolfe 2006; 2012). Coercion, normalization, and cooperation — central facets of colonial and settler colonial regimes - are thus intertwined in these stories and manifest in the spectacular battles over the landscape of East Jerusalem.

\section{Conclusion}


Landscape is too important to be allowed, any longer, to be the dreamwork-or the groundwork - of empire. Landscape studies must be dedicated to seeing that landscape becomes the groundwork - and dreamwork - of justice.

---Don Mitchell 2003, 793.

Once I sat on the steps by a gate at David's Tower. I placed my two heavy baskets at my side. A group of tourists was standing around their guide and I became their target marker. "You see that man with the baskets? Just right of his head there's an arch from the Roman period. Just right of his head." "But he's moving, he's moving!" I said to myself: "redemption will come only if their guide tells them, 'You see that arch from the Roman period? It's not important: but next to it, left down and a bit, there sits a man who's bought fruit and vegetables for his family.",

---Yehuda Amichai, Tourists

This article sought to explore the national parks apparatus in East Jerusalem and its complex enterprise of landscape production that fuses the national with the vernacular. Recalling my own childhood experience of the East Jerusalem landscape, I showed how Israel has been positioning itself as a green nation that cares for the region's natural resources and that preserves them for everybody's benefits. Interviews with INPA officials illustrate, accordingly, that they perceive their task as one that protects the true underdogs of the region-nonhuman animals such as finches and gazelles as well as ancient agricultural traditions such as terraces and springsand not as one aimed at discriminating against Palestinians. This, in fact, is portrayed as an unpleasant and undesirable byproduct that arises from the fundamental and inherent clash between the Palestinian culture, and their perceived barbaric treatment of nature and animals, with Israel's more progressive nature protection agenda. This article attempted to show that such a designation of national parks and other traditional forms of nature protection are an integral part of a (settler) colonial infrastructure, which shares much in common with multiple sites of conservation around the world (Agrawal and Redford 2009; Davis 2013; Peluso 1993; Spence 1999), thus further illuminating why conservation and justice are so often depicted as adversarial projects. 
In the two national parks studied here, the presence of the Palestinian residents - who currently own and cultivate the lands and who in some cases have often dwelled on it for centuries - has become subordinate to the reconstruction of an imagined landscape of nof kdumim. This particular imaginary landscape is in turn projected onto the physical landscape in East Jerusalem by Israel's nature protection agency. This kind of nature preservation occurs through active practices of erasing and making the landscape, which on the one hand require the elimination of Palestinian "refugee camps" and, on the other hand, elevates, essentializes, and protects the agrarian terrace landscape ("adam ba'har"). The legal protection of this natural landscape in turn facilitates the narrative of past Jewish indigeneity, thereby supporting nof kdumim, or the ancient landscape.

Throughout, I emphasized the crucial role and the heightened rule of law in the making of the natural landscapes of this place, stressing how systems of regulation and governance are coproduced alongside the ongoing making of cultural and material worlds (Wylie 2007, 190). In other words, I showed how landscape is "a particular sort of legal and political entity" (Olwig $2002,19)$. Rather than being static and fixed, the landscape thus emerges as a malleable and interactive scene that fluctuates between the extremes of legal and illegal, personal and collective, memory and erasure, belonging and exile, dwelling and movement, and integration and coercion. Finally, I also highlighted the hybridity of the East Jerusalem landscape as it embodies a mix of colonial and settler colonial features. Accordingly, Silwan's Palestinian residents are dispossessed from their homes as the land literally collapses from beneath them (or is demolished upon them) — presenting a typical colonial setting — while in Walaje an understanding that the terraces of the Jewish forefathers need to be routinely attended to has 
resulted in that the local fellahin are tolerated and even idealized in certain instances (but not always, as documented by Joronen 2019) — thereby presenting a typical settler colonial scheme.

The technology of dispossession depicted in this article — the severing of Palestinians from their lands through their designation as nature reserves and national parks - is symbolic as much as it is physical. The Palestinian farmer is now made to serve the Zionist narrative of redemption and return, as her presence is subsumed into a past of historic significance that is not her own. And while the rule of law and the innocuousness of nature are utilized to redesign the natural landscape as one that is in need of protection by Israel's nature authorities, on the ground actors simultaneously operate to normalize these sites as displays of historical Jewish significance in the service of environmental and archeological tourism. The natural landscape has been recruited, only to discover that it has always been Jewish.

\section{Acknowledgements}

I would like to thank the article's anonymous reviewers for their excellent comments and the Baldy Center for Law \& Social Policy for its financial support. This article is dedicated to the child who wandered through Jerusalem's winding paths for so many hours, always on the edge. To my Jerusalem.

\section{References}

Abu El-Haj, Nadia. (2008). Facts on the Ground: Archaeological Practice and Territorial SelfFashioning in Israeli Society. University of Chicago Press.

Abu Bassem (pseudonym). Palestinian resident, Walaje, East Jerusalem. In-person interview \& tour of land, January 11, 2017.

Agrawal, Arun and Kent Redford. (2009). Conservation and Displacement: An Overview. Conservation and Society 7(1): 1-10. 
Allegra, Marco, Handel, Ariel, and Erez Maggor (eds.). (2017). Normalizing Occupation: The Politics of Everyday Life in the West Bank Settlements. Indiana University Press.

Bardenstein, Carol. (1998). Threads of Memory and Discourses of Rootedness: Of Trees, Oranges, and the Prickly Pear Cactus in Israel/Palestine. Edebiydt 8(1): 9.

BBC. (2010). “Archeology and the Struggle for Jerusalem.” Katya Adler. Feb. 5. http://news.bbc.co.uk/2/hi/8480304.stm.

Berda, Yael. (2017). Living Emergency: Israel's Permit Regime in the Occupied Territories. Stanford University Press.

Bimkom. (2012). From Public to National: National Parks in East Jerusalem. http://bimkom.org/eng/wp-content/uploads/From-Public-toNational_English_FINAL2012_withMAPS_lowres1.pdf.

B’Tselem. (2019). "Self-Destruction”: Palestinians in East Jerusalem Forced to Demolish Own Homes. April 28. https://www.btselem.org/video/20190428_self_destruction_jm_municipality_forcing_pal estinians_to_demolish_their_own_homes\#full.

Busbridge, Rachel. (2018). Israel-Palestine and the Settler Colonial ‘Turn’: From Interpretation to Decolonization. Theory, Culture \& Society 35(1): 91-115.

Braverman, Irus. (n.d.). Beastly Legalities: Regulating Wild Life in Palestine/Israel. PoLAR (under review).

-----. (2019). Silent Springs: The Nature of Water and Israel's Military Occupation. Nature and Space: Environment and Planning E (forthcoming, first published 27 June). https:/journals.sagepub.com/doi/abs/10.1177/2514848619857722?journalCode=enea.

-----. (2015). Wild Life: The Institution of Nature. Stanford: Stanford University Press. 
-----. (2014). Conservation without Nature: The Trouble with In Situ versus Ex Situ

Conservation. Geoforum 51: 47-57.

-----. (2009). Planted Flags: Trees, Land, and Law in Israel/Palestine. Cambridge: Cambridge University Press.

(2007). Powers of Illegality: House Demolitions and Resistance in East Jerusalem. Law and Social Inquiry 32(2): 333-372.

Chiodelli, Francesco. (2017). Shaping Jerusalem: Spatial Planning, Politics, and the Conflict. New York: Routledge.

Cohen Bar, Efrat. Planner, Bimkom. In person interview, February 16, 2018. Bimkom offices, Jerusalem, Israel.

Cohen Lifshitz, Alon. Planner, Bimkom. In person interview and observations, February 19, 2018, West Bank.

Davis, Diana K. (2013). Imperialism, Orientalism, and the Environment in the Middle East. In: Davis Diana K. and Burke E III (eds) Environmental Imaginaries of the Middle East and North Africa. Ohio University Press, pp.1-22.

Dubow, Jessica. (2004). The Mobility of Thought: Reflections on Blanchot and Benjamin. Interventions: International Journal of Postcolonial Studies 2(1): 87-102.

Emek Shaveh. (2019a). Putting an End to Elad's Religious Discrimination at the Gihon Spring. https://alt-arch.org/en/discrimination-at-the-gihon-spring/.

-----. (2019b). Wall from Early Islamic Period Prevents Continued Excavation of Tunnel between Silwan and the Old City. March 20. https://alt-arch.org/en/wall-from-earlyislamic-period/. 
-----. (2019c). Six Feet Under: The Cultural Heritage of Minorities in Jerusalem. May 21. https://alt-arch.org/en/six-feet-under/.

-----. (2018). On which Side is the Grass Greener? National Parks in Israel and the West Bank. https://alt-arch.org/en/grass-greener_en/.

-----. (2014a). A Privatized Heritage: How the Israel Antiquities Authority Relinquished Jerusalem's Past. http://alt-arch.org/en/wp-content/uploads/2014/11/Privatized-HeritageEnglish-Web1.pdf.

------. (2014b). From Territorial Contiguity to Historical Continuity: Asserting Israeli Control through National Parks in East Jerusalem - Update 2014 (see section on Kidron).

-----. (2013). From Silwan to the Temple Mount: Archaeological Excavations as a Means of Control in the Village of Silwan and in Jerusalem's Old City - Developments in 2012 [Hebrew original, published February 2013].

Fields, Gary. (2010). Landscaping Palestine: Reflections of Enclosure in a Historical Mirror. Int. J. Middle East Stud. 42: 63-82.

Greenberg, Rafi. (2009). Towards an Inclusive Archeology in Jerusalem: The Case of Silwan/The City of David. Public Archeology 8(1): 35-50.

Haaretz. (2018). Opinion: How Jewish Settlers Are Cementing Their Rule Over Palestinians in Jerusalem. November 15, By Betty Herschmann. https://www.haaretz.com/israelnews/.premium-how-jewish-settlers-are-cementing-their-rule-over-palestinians-injerusalem-1.6655809.

-----. (2017). Israel Declares Five New National Parks and Nature Reserves. by Zafrir Rinat. June 26. https://www.haaretz.com/israel-news/.premium.MAGAZINE-israel-declaresfive-new-national-parks-and-nature-reserves-1.5489032. 
Handel, Ariel, Rand, Galit, and Marco Allegra. (2015). Wine-Washing: Colonization, Normalization, and the Geopolitics of Terroir in the West Bank's Settlements. Environment and Planning A 47: 1351-1367.

Haraway, Donna J. (2003). The Companion Species Manifesto: Dogs, People, and Significant Otherness.Vol.1. Chicago: Prickly Paradigm Press.

Hatzofe, Ohad. INPA. In-person interview by author, August 7, 2019 at Zichron Yaakov, northern Israel, and participant observation turtle program, northern beaches, August 10, 2019.

Howkins, Adrian, Orsi, Jared, and Mark Fiege (eds). (2016). National Parks Beyond the Nation: Global Perspectives on “America's Best Idea." University of Oklahoma Press.

Imadeddin, Albaba. (2017). Current Status of Nature Reserves in Palestine. Journal of Entomology and Zoology Studies 5(1): 618-621.

INPA (2019). About Us. https://www.parks.org.il/en/about/.

INPA official "A.” Telephone interview with author, September 11, 2018

INPA official "B.” Telephone interview with author, September 24, 2018.

INPA official "C." In-person interview and observations, East Jerusalem and Judean Hills, February 16, 2018.

INPA official “D.” Telephone interview, July 15, 2019.

Israel Ministry of Foreign Affairs. (2015). https://mfa.gov.il/MFA/AboutIsrael/Pages/ISRAEL\%20IN\%20BRIEF.aspx.

Joronen, Mikko. (2019). Negotiating Colonial Violence: Spaces of Precarisation in Palestine. Antipode 51(3): 838-857.

Katz-Mink, Elana. (2012). Dangerous Separation: An Ecosystem and Way of Life in the West 
Bank at the Brink of Destruction. Sustainable Development Law \& Policy 13(1): 47-70.

Kersel, Morag M. (2015). Fractured Oversight: The ABCs of Cultural Heritage in Palestine after the Oslo Accords. Journal of Social Archeology 15(1): 24-44.

Leigh Star, Susan and James R. Griesemer. (1989). Institutional Ecology, "Translations” and Boundary Objects: Amateurs and Professionals in Berkeley's Museum of Vertebrate Zoology, 1907-39. Social Studies of Science 19(3): 387-420.

Long, Joanna C. (2009). Rooting Diaspora, Reviving Nation: Zionist Landscapes of PalestineIsrael. Transactions of the Institute of British Geographers 34(1): 61-77.

Mishirqi-Assad, Quamar. Advocate \& Co-Director, Haqel: In Defense of Human Rights. Interviews and observations, January 2017 - February 2018.

Mitchell, Don. (2003). Cultural Landscapes: Just Landscapes or Landscapes of Justice? Progress in Human Geography 27(6): 787-796.

W.J.T. Mitchell (ed.). (1994). Landscape and Power. University of Chicago Press.

Mizrachi, Yonathan. Director, Emek Shaveh. In-person interview, Jerusalem, Israel. January 1, 2017.

Noam, Amichai. Director, Gush Etzion Field School. In-person interview at interviewee's home, Tkoa settlement, Area C. July 3, 2019.

Olwig, Kenneth. (2005). Editorial: Law, Polity and the Changing Meaning of Landscape. Landscape Research 30(3): 293-298.

-----. (2002). Landscape, Nature, and the Body Politic. Madison: University of Wisconsin Press. Peluso, Nancy L. (1993). Coercing Conservation? The Politics of State Resource Control. Global Environmental Change 3(2): 199-217. 
Reynolds, Kyra Marie. (2017). Unpacking the Complex Nature of Cooperative Interactions: Case Studies of Israeli-Palestinian Environmental Cooperation in the Greater Bethlehem Area. GeoJournal 82(4): 701-719.

Said, Edward W. (2000). Invention, Memory, and Place. Critical Inquiry 26(2): 175-192.

Schein, Richard. (2003). Normative Dimensions of Landscape.” In Wilson C. and Groth P. (eds.). Everyday America: Cultural Landscape Studies after J.B. Jackson. Berkeley: University of California Press.

Schorr, David. (2014). Forest Law in Mandate Palestine: Colonial Conservation in a Unique Context. In Uwe Luebken \& Frank Uekötter (eds.). Managing the Unknown: Essays on Environmental Ignorance, 71-90. Berghahn Books.

Sebald, W.G. (1998). The Rings of Saturn. London: Harvill Press.

Shlomo, Oren. (2017). The Governmentalities of Infrastructure and Services Amid Urban Conflict: East Jerusalem in the Post Oslo Era. Political Geography 61: 224-236.

Shuster, Ruth and Nir Hasson. (2018). First Temple-era, Early Christian Ruins Featured in New Archaeological Park Near Jerusalem. Haaretz. February 4.

Spence, Mark David. (1999). Dispossessing the Wilderness: Indian Removal and the Making of National Parks (New York, Oxford: Oxford University Press).

Tamari, Salim. (1981). Building Other People's Homes: The Palestinian Peasant's Household and Work in Israel. Journal of Palestine Studies 11(1): 31-66.

Tatarski, Aviv. Founder, Engaged Dharma \& instructor, Ir Amim. Skype \& in-person interviews, December 23, 2016 \& January 11, 2017 (Walaje).

Tawil-Souri, Helga. (2012). Uneven Borders, Coloured (Im)mobilities: ID Cards in Palestine/Israel. Geopolitics 17(1):153-176. 
UN Human Settlements Programme. 2015. Right to Develop: Planning Palestinian Communities in East Jerusalem: UN-Habitat Report. https:/unhabitat.org/books/right-to-developplanning-palestinian-communities-in-east-jerusalem/

UNESCO. (n.d.). Palestine: Land of Olives and Vines - Cultural Landscape of Southern Jerusalem, Battir. https://whc.unesco.org/en/list/1492.

Veracini, Lorenzo. (2013). The Other Shift: Settler Colonialism, Israel, and the Occupation. Journal of Palestine Studies 42(2): 26-42

-------. (2006). Israel and Settler Society (Pluto Press).

Wolfe, Patrick. (2012). Purchase by Other Means: The Palestine Nakba and Zionism's Conquest of Economics. Settler Colonial Studies 2(1): 133-171.

--------. (2006). Settler Colonialism and the Elimination of the Native. Journal of Genocide Research 8(4): 387-409.

Wylie, John. (2007). Landscape. London \& NY: Routledge.

Yiftachel, Oren. (2009). Critical Theory and "Gray Space”: Mobilization of the Colonized. City 13(2-3): 246-263.

Zerubavel, Yael. (1995). Recovered Roots: Collective Memory and the Making of Israeli National Tradition. University of Chicago Press.

Zureik, Elia. (2015). Israel's Colonial Project in Palestine: Brutal Pursuit. Routledge. 